\title{
Exercising the Politics of Salvation: Analyzing Foreign Policy Responses of India and Turkey during Humanitarian Crises (2014-2019)
}

\author{
Hadza Min Fadhli Robby \\ ${ }^{1}$ Department of International Relations, Faculty of Psychology and Socio-Cultural Sciences, \\ Islamic University of Indonesia, Yogyakarta \\ \{hadza.fadhli@uii.ac.id\}
}

\begin{abstract}
The research investigates the Indian and Turkish policy responses toward the humanitarian crisis, which prompts both countries to conduct salvation politics. While working its politics of salvation, Turkey and India used religious pretexts to protect their fellow faithful from neighboring countries' These two countries were chosen because both countries have been undergone a long-term secularization process, while at the same time experienced multiple religious resurgences as a counter-movement against state-led secularism. This research argues that the conduct of the politics of salvation will influence both countries' outlook on religious freedom, albeit not in favorable terms. Both countries are trying to protect their fellow faithful against their constructed 'others' ('violent-radical Islam' and 'Shia/authoritarian Islam,' respectively). This research would like to engage with the concept of "politics of principled pluralism," developed by Robert Joustra.
\end{abstract}

Keywords: Humanitarian Crisis; Foreign Policy; India; Turkey; Political Theology in International Relations; Politics of Principled Pluralism

\section{Introduction}

Not until recently that religion has taken a more important place in international politics. The resurgence of religion does not mean that global politics will lead to a new episode of conflicts, as some experts have argued. It is also important to note that religion has contributed to peacebuilding and conflict resolution in conflict-ridden societies. Despite the rise of fundamentalist and radical religious movements that viewed international politics as a ground of conflict, religious leaders and communities' roles in pursuing positive change and progress in political and societal crises also need to be emphasized. Therefore, it should be noted that the fault lines between different religions and civilizations would not always lead to perpetual and apocalyptic warfare. Instead, the projection of religious vision by state/non-state actors in global politics will be dependent upon how they will interpret the religion and the religious worldview. As Haynes said in his monumental work, religion's role in international politics is often ambiguous and depended entirely upon the political context and the actors' intention. In this context, a specific country's foreign policy could indeed be based upon a particular religious value, but by no means that it will always be a violent or a peace-oriented policy [1]

Ever since the September 11th tragedy occurred, religious pretext in foreign policy implementation is becoming more prominent. As Haynes has categorized in his book, there are at least two types of 
interactions between religion and foreign policy [1]. The first interaction that was identified by Haynes is that religious values could consistently drive foreign policy. This interaction could be seen mostly in countries established under particular religious values or principles. Iran, Saudi Arabia, and Pakistan are examples of countries that display close interaction between religion and foreign policy. The second interaction is the intermittent centrality of religious concerns in the foreign policies of several countries. One of the examples that could be mentioned is the example of the United States' foreign policy after 9/11. The passage of free exercise in the First Amendment of the US Constitution stipulates religion's nature in the American domestic and foreign policy. Thus, following the September 11th crisis, the Bush administration addressed the attack by evoking the notion of 'global war against terror,' which eventually delineates the term 'axis of evil' [2]. Regarding the categorization explained above, this paper would like to discuss the foreign policies of two separate countries, India and Turkey, in the moments of the humanitarian crisis.

India and Turkey were as e studies because both countries are known for adopting the secular political system. This adoption of secularism as a political outlook, has been facing severe challenges from political actors and intellectual alike, particularly those who are subscribing to the idea of rightwing politics. While Turkey has seen the ascent of AK Parti in Turkey contributed to the resurgence of conservative ideas amid neoliberal authoritarianism, India witnessed the rise of BJP in India, eventually lead to a re-interpretation and re-reading on the idea of secularism previously offered by the ancien regime of Congress Party. While developing its new narratives on secularism and the relations of religion and politics, both countries are also trying to strengthen their self-identity against any kind of threat. Especially the threats originated from their enemies/others. This effort to strengthen self-identity eventually influenced the foreign policies of both India and Turkey. To strengthen their self-identity, India and Turkey used religious pretexts and principles when faced with a humanitarian crisis. Both countries are located in a hostile and unfriendly neighborhood. In the case of Turkey, Turkey is facing a hostile engagement with its closest neighbor, Syria. During the implementation of an open-door policy to welcome refugees and political oppositions from Syria. During the Syrian Civil War, by accepting with the pro-democratic Sunni Muslim refugees, Turkey is trying to build a straightforward narrative to become a savior for (pro-democratic) Sunni Muslim in Syria and the Middle East [3].

In India's case, India seeks to protect the persecuted Hindu, Buddha, Sikh, and Christian adherents from the discriminatory policies implemented by the governments and societies of Bangladesh, Afghanistan and Pakistan [4]. By passing new legislation that would amend the existing Citizenship Act, India would also like to strengthen its position and strengthen Hinduism in the South Asian region. While discussing the persecutions that happened in the mentioned countries, India often correlated the discriminatory practices with the lack of respect toward democracy and human rights. While strengthening its credential as a savior of the persecuted rights, India is neglecting India's Muslim rights by disenfranchising the Muslims from public life. This contradiction could be seen as a struggle of India to find its real self. To save its part of the Hindu needs, India needs to forsake its secular principles and categorize Indian Muslims as part of the Indian' other'. In this paper, the case of Turkish and Indian involvement in the humanitarian crisis would be discussed and compared in detail. This research aims to find the connection between Turkish and Indian foreign policies with pretexts and justifications based upon religious values and texts to respond toward imminent dangers of the humanitarian crisis that would affect fellow believers' lives in neighboring regions. Looking at how both countries tried to show themselves as the protector of refugees, Turkey and India are trying to conduct their salvation politics. The term 'politics of salvation' here is 
drawn from the examples of how Moses successfully liberated the Israelites from the persecution of Pharaoh.

Based on the mentioned aims, the main research question that seeks to be answered in this research is how certain countries, with India and Turkey as case studies, try to justify and establish its foreign policy during humanitarian crises by using religious pretexts? Since the topic discussed is focused on the implementation of both Indian and Turkish foreign policies, it is necessary to limit the research into a specific time boundary. Therefore, in this case, the time boundary that would be set in order to make the research more focused is between the years of 2014 to 2019. During those years, both Turkey and India are ruled by the conservative right-wing party, which are Adalet ve Kalkinma Partisi and Bharatiya Janata Party, respectively. Due to the time constraints, vast geographical distances, and the difficulties of accessing the primary sources and data, most of the materials used in this research will be derived from secondary sources such as books, literary works, reports, newspapers, and news from online media. The data provided in this research are retrieved from both official and non-governmental institutions in Turkey and India. This research uses two case studies separately in Turkey and India to better understand the usage of religious pretexts in Turkey and India's foreign policies. This research also methodologically refers to the qualitative research method. During the analysis process, data gathered during the research will be analyzed with conceptual frameworks explained in detail below.

\section{Conceptual Framework}

\subsection{International Political Theology}

The advent of political theology in the field of international relations is a relatively novel phenomenon. As a discipline, international relations have always been correlated with the notion of modernity and secularity. Traditionally, the discipline of international relations has always assumed that religious factors would play a limited and liminal role in international politics. According to Vendulka Kubalkova, this traditional assumption began to change gradually in the aftermath of 9/11. The view that modernity would always bring civilizations, communities, or nation-states into an irreversible development path has found its limitation. In some instances, it is evident that superstition and beliefs, whether in the form of cultural, religious, or ideological values, would be seeping into the realm of political and economic progress. Kubalkova argues that the old notion that modernity and religion could not be related to each other is not relevant anymore. Therefore, extensive research on the relations between modern international politics and religion under the sub-discipline of international political theology needs to be conducted [5].

To research issues related to international political theology, some things should always be kept in mind. According to Kubalkova, the international political theology (later will be mentioned as IPT) needs to avoid using the positivist methodology in its research. Positivist methodology would not acknowledge any possibility that transcendental values like religion, theology, or cultural values could be used as evidence or basis to do the substantive analysis of individual countries' behavior in its conduct in international political affairs. Second, Kubalkova also highlighted the importance of analyzing religious texts and their influence in international politics. According to the concept of international political theology, religious texts have been the central resource of the actor's intention and the primary mover of foreign policy orientation. Third, as IPT is a newly-founded concept developed from the Constructivist framework, it is also important to remind that IPT should also recognize the different forms of rationality across civilization. Instead of promoting moral universalism, IPT would seriously challenge the assumption by saying that international relations could 
and should be an inclusive discipline that could engage with various religious and civilizational discourse instead of discarding it.

\subsection{Principled Pluralism, Religious Freedom and Foreign Policy}

In his seminal work on religion and foreign policy, Dr. Robert Joustra tried to elaborate on the importance of positioning political theology correctly in contemporary international politics. Before explaining further issues on religious freedom and foreign policy, Joustra clarified that it is essential to settle the definition of political theology. According to Joustra, political theology is an understanding and practices that political actors have about the meaning of and the relationship between the religious and the secular, and what constitutes legitimate political authority. Based upon this definition of political theology, Dr. Joustra eventually made the following table to rival versions of the religious and the secular affairs in public affairs [6].

Table 1. Rival versions of the religious and the secular in the public affairs

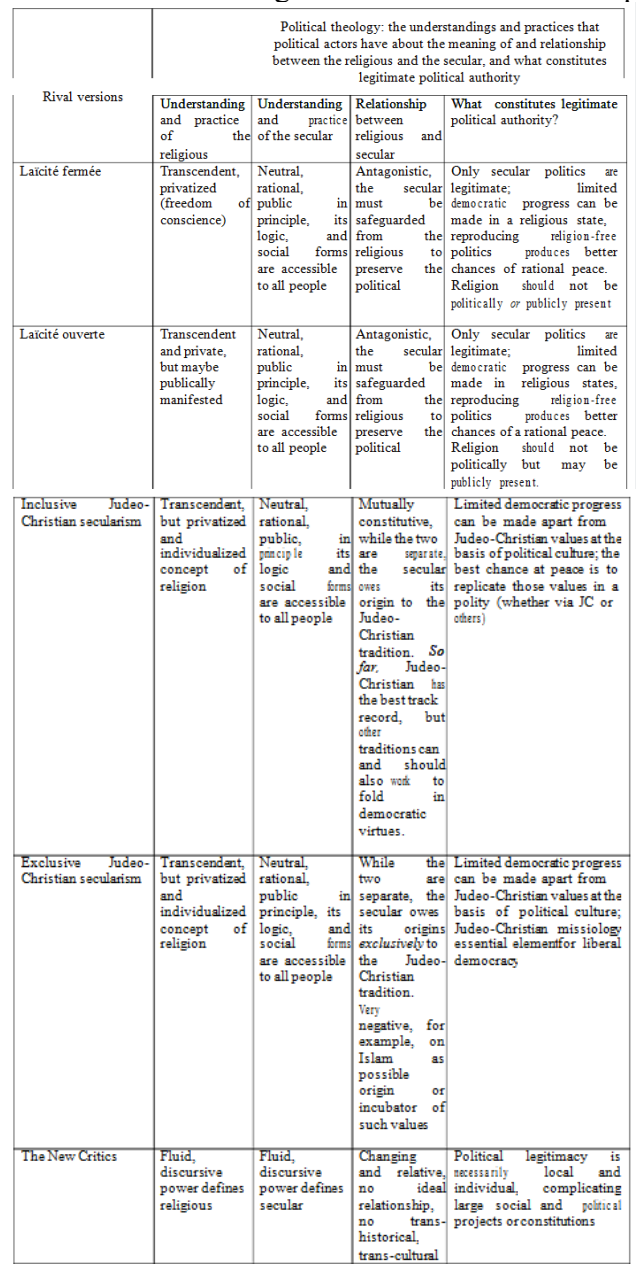




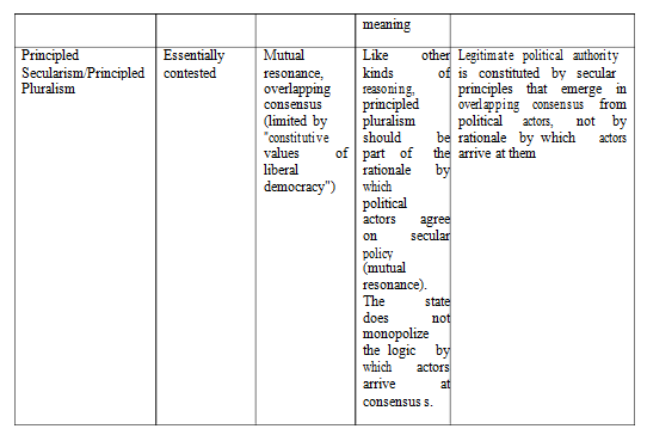

According to Joustra, principled pluralism is a practical framework that could be engaged in thinking about foreign affairs in a post-secular world. Joustra argued that since principled pluralism is an advancement of strong public principles that need not be based upon monopolization of public logic. In the context of principled pluralism, both secular and religious actors could establish their 'full rationales' to pursue a politics of diversity and mutual understanding, especially between groups with opposing worldviews. Joustra also argues that principle pluralism could a compromise between two extreme choices of ontological exclusivism (as strived by right-wing extremist) and cosmopolitan paralysis (as pursued by liberals). In this paper, the concept of principled pluralism would be used to see the usage of religious narratives in Turkey and India, which are currently undergoing a process of strong homogenization of conservativism. In line with that explanation, the analysis would also include the development of secularism in both countries and how it eventually experienced significant transformation, especially after a humanitarian crisis [6].

\section{Result and Discussions}

It is necessary to begin the discussion by explaining the religious and secular politics in Turkey and India. Looking at its constitution, Turkey could still be considered as a secular nation. The constitution stipulated key is declaring itself to be a laik or laicist nation. The notion of laicism in Turkish political thought found its way in the $19^{\text {th }}$ century, during fundamental political reform in the Ottoman Empire. Laicism was adopted as one of the modern Turkish state principles to find Turkish place within the modern Western civilization. Turkish choice for laicism was indeed a political and cultural sacrifice for many Turks who are predominantly Muslim and have been holding back to their religious and cultural values for many centuries [7]. The dominant secularist discourse was not being challenged until recently when a critical mass of conservative Muslim Turks working as entrepreneurs, bureaucrats, and intellectuals started to reclaim their public sphere once lost to the secularists. During this time, Turkey underwent an evaluation process that led Turkey into a process of post-Islamization and postsecularization. During this process, AKP, as a political representation of the previously-marginalized silent majority of conservative Muslim Turks, emerged as a victor in the 2003 election. Slowly but sure, AKP is starting to challenge the strong notion of laicism in Turkish politics by introducing religious values and principles, both in governmental bodies and in broader Turkish society [8].

As Turkey established its new narrative of the religion-politics boundary in its homeland, many Arab countries experienced a wave of democratization brought by the Arab Spring. Arab Spring has introduced many Arab countries to the Turkish model of democratization. In this case, Turkey started to show itself as a leader and role model for Arab and Muslim countries. Nevertheless, as Turkey experienced mass protests during the Gezi Park movement, many questioned Turkish credentials as a democratic country. Eventually, Turkey finds another way to strengthen its own 'conservative 
democracy' narrative in the Middle East by involving in the Syrian crisis, both politically and militarily [9]. The implementation of the 'open door' policy by Turkey was in line with the Turkish plan to strengthen its leadership amongst Sunni Muslim countries in the Middle East and the World. By invoking the narratives of 'Bizler Ensar, sizler muhacir,' the Turkish government under Erdogan's leadership is trying to position itself as a guarantor (ensar) of the persecuted Sunni (muhacir) from the authoritarian Syrian regime, which is considered similar to the infidel Quraisy community [10]. This event proves that Erdogan is trying to follow the Sunni principles of political theology, which was trying to avoid people from falling into Shiite domination. This current tendency shows that Turkey is re-evaluating its laicism principles (particularly in the category of laicite fermee) to be Turkish-style secularism [11]. The new vision of Turkish-style secularism is still in the process of making, as Turkey is still building a new consensus to reach a new version of 'principled pluralism.'

As with India, India's constitution underlined the adoption of secularism as one of the main pillars in modern Indian politics. Secularism was not originally part of the Indian constitution, but India has adopted a distancing policy from existing religions since its independence as a modern nation-state. Due to the sensitivities resulted from the bloody process of 1947 Partition, India, in the beginning, tried to give much attention to the minority religious groups while also making comprehensive policies that would satisfy the majority Hindu population. From 1947 until the 1976 amendment, which added the 'secular' clause to the Indian constitution's preamble, India was a country that adopted some parts of the inclusive Judeo-Christian secularist tradition from colonial British [12]. It is not necessarily a laicist system since the government merely adopted the British model on governing religious affairs in colonial India. The Indian government realized the need for a more stable and secure government; the clause 'secular' is added to ensure that the government would not implement certain religious groups' policies. Policies were being constructed by the Indian government to ensure that communal violence would not hamper national unity in India.

Nevertheless, some Indians got disillusioned with the idea of secular India. According to right-wing politicians and scholars in India, the idea of secular India was never meant to protect the state's neutrality against any religion [13]. Instead, it is argued by many right-wing scholars that Indian secularism was being implemented as a way to appease the minority religious groups, especially the Muslims. 
This kind of narrative was brought mainly by the Hindu-nationalist organization RSS and its political wing BJP. As both RSS and BJP secured domination by propagandizing secularism and minority appeasement, India is also experiencing significant economic development growth [14]. The effort of the BJP to secure the majority vote in the Central government was finally guaranteed in 2014. Starting from this year, BJP shows itself as a party for all Indians with the slogan of sabka saath sabka vikas (development for all) [15]. However, on the other hand, BJP and RSS are willing to create stronger Hindutva/Hindu nationalism narratives. Hindutva's political theology is based upon vengeance politics, which is significantly based upon the hatred of Muslim domination, which is considered to have colonized India for centuries before the arrival of British colonial rule. Hindutva is trying to create a single united body of Hinduism that could help achieve the goal of Akhand Bharat (united India), free from foreign domination (which includes Muslim) [16]. Hindutva could also be considered a project to make Hindu organized like a monotheistic religious community, as found in the Muslim ummah case [17]. Hindutva has already made its way in influencing the Indian domestic policies directly, but not directly influencing the Indian foreign policy. In 2019, the Indian government started a new debate to amend the existing Citizenship Act; many worried that this act would eventually be a turning point in Indian politics. As Citizenship Amendment Bill stipulates, the Bill would provide a fast-lane citizenship application process of Hindu, Buddha, and Sikh refugees coming from neighboring Muslim countries in South Asia. The Bill's acceptance has caused many negative consequences, especially in making Muslims as 'other' and 'second-class citizen' in a quasi-secular India [18]. In this context, the government of India would like to develop a new conception of secularism. In Hindutva's perspective, secularism should be dictated accordingly with what the majority Hindu wants and should be in line with Hindu values [19]. Thus, it could be concluded that the effort to reach 'principled pluralism' is more challenging in the context of India due to the strong communal feelings.

\section{Conclusion}

This research would like to conclude that Turkey and India were founded upon the principles of secularism. While Turkey experienced a challenging secularization through the imposition of laicism, India had its own experience in dealing with British-style secularism and the bloody legacies of the 1947 Partition, which separated Muslim-majority Pakistan from India. When the conservatives regained their influence from the population, the value of secularism would be facing a severe challenge. The narrative of secularism was being re-defined in the momentum of crisis. The momentum of crisis did not end in discovering 'principled pluralism' in both countries, as Turkey is still negotiating Turkish-style secularism, while India is still facing a serious threat of ever-heightened communal violence.

\section{Acknowledgements}

The author would like to thank Professor Robert Joustra from Redeemer University in Canada for his kind inputs. The author would also like to thank the Faculty of Psychology and Socio-Cultural Sciences and the Department of International Relations, the Islamic University of Indonesia, for the material and financial supports provided during the research. 


\section{References}

[1] J. Haynes, An Introduction to International Relations and Religion, New York: Routledge, 2014.

[2] G. Robertson, "Confronting the "Axis of Evil": Christian Dispensationalism, Politics and American Society Post-9/11," Journal of Muslim Minority Affairs, vol. 34, no. 2, pp. 111-122, 2014.

[3] S. Kloos, "The Neo-Ottoman Turn in Turkey's Refugee Reception Discourse," Alternatif Politika, vol. 8, no. 3, pp. 536-561, 2016.

[4] T. Khan, "The Citizenship Amendment Act, 2019: A Religion Based Pathway to Indian Citizenship," 21 April 2020. [Online]. Available: https://dx.doi.org/10.2139/ssrn.3665743.

[5] V. Kubalkova, "Towards an international political theology," Millenium, vol. 29, no. 3, pp. 675704, 2000.

[6] R. Joustra, The Religious Problem with Religious Freedom, New York: Routledge, 2017.

[7] A. Kadığlu, "The pathologies of Turkish republican laicism," Philosophy \& Social Criticism, vol. 36, no. 3-4, pp. 489-504, 2010.

[8] M. Gunter and M. H. Yavuz, "Turkish Paradox: Progressive Islamists versus Reactionary Secularists," Critique: Critical Middle Eastern Studies, vol. 16, pp. 289-301, 2007.

[9] E. F. Keyman, "Turkish foreign policy in the post-Arab Spring era: from proactive to buffer state," Third World Quarterly, vol. 37, no. 12, pp. 2274-2287, 2016.

[10] Sabah, "Cumhurbaşkanı Erdoğan: Bizler Ensar sizler muhacir," Sabah, 7 October 2014.

[11] M. H. Yavuz and A. E. Öztürk, "Turkish secularism and Islam under the reign of Erdoğan," Southeast European and Black Sea Studies, vol. 19, no. 1, pp. 1-9, 2019.

[12] D. E. Smith, India as a Secular State, Princeton, NJ: Princeton University Press, 1967.

[13] G. Prakash, "Secular Nationalism, Hindutva, and the Minority," in The Crisis of Secularism in India, Durham and London, Duke University Press, 2007, pp. 177-190.

[14] B. R. Nayar, "The Limits of Economic Nationalism in India: Economic Reforms under the BJPLed Government, 1998-1999," Asian Survey, vol. 40, no. 5, pp. 792-815, September-October 2000.

[15] SNS Web, "PM Modi reiterates 'Sabka Saath, Sabka Vikas, Sabka Vishwas' motto at UN ECOSOC virtual meet," The Statesman, 17 July 2020. [Online]. Available:

https:/www.thestatesman.com/india/pm-modi-reiterates-sabka-saath-sabka-vikas-sabkavishwas-motto-at-un-ecosoc-virtual-meet-1502909558.html. [Accessed 3 November 2020].

[16] E. Leidig, "Hindutva as a variant of right-wing extremism," Patterns of Prejudice, vol. 54, no. 3, pp. 215-237, 2020.

[17] A. Basu, Hindutva as Political Monotheism, Durham \& London: Duke University Press, 2020.

[18] M. M. A. Bhat, "The Constitutional Case against the Citizenship Amendment Bill," Economic \& Political Weekly, pp. 12-14, 19 January 2019. A. Chandrachud, "Secularism and the Citizenship Amendment Act," Indian Law Review, vol. 4, no. 2, pp. 138-162, 2020.

[19] Available: https://www.sabah.com.tr/aktuel/2014/10/07/cumhurbaskani-erdogan-bizler-ensarsizler-muhacir?paging=5. [Accessed 3 November 2020]. 